\title{
Conflict of Interest in the Administrative Contracts in Albania
}

\author{
Adriatik Llalla, PhD Candidate \\ General Prosecution Office of the Republic of Albania \\ PhD Fjorida Ballauri \\ General Prosecution Office, Albania
}

doi: 10.19044/esj.2016.v12n34p182 URL:http://dx.doi.org/10.19044/esj.2016.v12n34p182

\begin{abstract}
In Albania the issue of conflict of interest is present at today's public debate, as in many other countries. Due to this phenomenon, public funds, state property, public service, etc., are at risk at any time, and therefore there is obligation of the state to establish the appropriate legal instruments to prevent such situations. In principle, while exercising official duties and functions, the elected person or the public official should not be influenced by personal interests. In this sense, through actions, inactions or decisions, they cannot gain benefits or advantages for themselves, their family members, relatives or other persons, in case they share economic or political interests with them. In Albania, the domestic legislation provides restrictions and prohibitions for several private interests of the officials exercising public functions, depending on their functions, responsibilities and competencies in public decision-making. Also, the law provides specific prohibitions and restrictions in cases of entering into administrative contracts, considering a contract as a special public decision, which is vulnerable to be damaged by the action of officials' private interests. This paper aims to make an analysis of the legislation in terms of restrictions of private interests of public officials to prevent specific cases of conflict of interest while concluding administrative contracts. Also, the paper leads to conclusions on how conflict of interest is related to other criminal offences like abuse of office, corruption or violation of equality of participants in public tenders or auctions etc.
\end{abstract}

Keywords: Corruption, public officials, administrative contract, conflict of interest 


\section{Introduction}

Conflict of interest has become one of the most discussed issues in our everyday public debate, but also beyond. This is because the conflict of interest is directly linked to the life and welfare of the citizens, since due to this phenomenon, public service, public funds, state property etc., are at risk at any time. These areas are currently at higher risk of being affected by conflict of interest, corruption, abuse of office etc. It is already known that conflict between private interests and public official's functions can lead to corruption, if not managed properly. In a country with solid democracy, citizens should recognize and have proper transparency regarding the fact that where their contributions go through paid taxes, or how public funds are used, while businesses are also interested to this process, considered not only as indirect beneficiaries of public funds, as well as beneficiaries in conducting the process of redistribution. In this process, the state must ensure that public officials do not allow their private interests to influence their decisions. Failure to do so would weaken and violate the trust of citizens and public institutions.

In principle, all activities of public officials should be guided by some basic elements such as legality, protection of public interests and the rights of privacy of the person, equality, justice and impartiality, internal control, efficiency, etc., regulated mostly by the Code of Administrative Procedures and specific laws.

In 1998, Albania made a comprehensive integrated approach within the domestic legislation, focusing on the adoption of legislation and implementation of relevant laws with an active participation in international anti-corruption initiatives and the implementation of an anti-corruption strategy, through action plans to prevent and combat corruption monitored by specialized structures that were set up for this purpose.

After the signing the Stabilization and Association Agreement (SAA) on 12 June 2006, the approximation of legislation with the acquis communautaire and its application, constituted a very complex and very demanding process. It required that Albania will not only set up its regulatory framework according to these requirements, but it will also reassure the administrative structures and other conditions necessary for the implementation of the acquis.

The priorities of the Albanian institutions and ongoing requirements of various international organizations to strengthen the fight against the phenomenon of corruption in public administration, have been identified the end of 2004, and later was adopted a legislative package to the Penal Code and the Code of Criminal Procedure. These changes mainly affect the phenomenon of corruption in terms of defining more clearly the offense, as well as in terms of defining the tools and special methods of investigation, 
supporting the collection of evidence and reaching conclusions of this offense.

Part of this package was the adoption of the law no.9049, dated 04.10.2003 "On the declaration and audit of assets, financial obligations of elected and certain public officials” and the Law 9367, dated 07.04.2005 "On preventing conflicts of interest in the exercise of public functions”, as a new anti-corruption instrument in Albania.

\section{Concept of conflict of interest in the Albanian legislation}

In Albanian legislation, conflict of interest is defined by law, according to the same definition provided by the standard document recommended by the $\mathrm{OECD}^{3}$. The definition contains a general concept of conflict of interest and is divided into several sub-definitions of actual conflicts of interest, apparent and potential conflict of interest. These three types of conflicts of interest differ in relation to the effects of interest in decision-making.

Albanian law governing conflicts of interest, nr.9367, dated 07.04.2005 "On the prevention of conflict of interest in the exercise of public functions" as amended, in its Article 3.1 provides the following definition:

"Conflict of interest" is a situation of conflict between the public duty and the private interests of an official, in which he has direct or indirect private interests that affect, might affect or seem to affect in an incorrect way the performance of his public responsibilities and duties".

Meanwhile, according to various authors in this field ${ }^{4}$, the concept of conflict of interest does not refer to the actual violations, but more to the risk to be involved in violations of the law.

In exercising public functions, an officer may face different issues of conflict of interest, in the form of a) "Continuing conflict of interest" or what we call "inconsistent" with the public function and b) "Conflict of interest, considered case by case”, which is related to a particular decision-making of the official ${ }^{5}$.

The Albanian law on prevention of conflict of interest has foreseen several prohibitions of private interest of the public officials. Such restrictions are made to guarantee an impartial and transparent decisionmaking in the best possible interest of the public and of its trust in public

\footnotetext{
${ }^{3}$ OECD guidelines for managing conflict of interest in the public service, June 2003

${ }^{4}$ Bruno W. Speck, Conflict of Interest: Concepts, Rules and Practices regarding Legislators in Latin America,

The Latin Americanist, Volume 49, Issue 2, 2008 ,f. 67

${ }^{5}$ Article 3 "Definitions" of the Law no.9367, dated 7.4.2005, as amended
} 
institutions through preventing conflicts between public interests and private ones ${ }^{6}$.

Depending on the public position and the role in certain decisionmaking processes, the levels of limitations for the official's private interests are also defined by law. These limitations are potentially associated with the risk that these positions carry for illegal benefits or abuse of power.

The law nr.9367, dated 7.4.2005 “On the prevention of conflicts of interest in the exercise of public functions”, as amended, defines the private interest that can be considered a cause for the situation in a conflict of interest $^{7}$, these are as follows:

a) property rights and obligations of any kind;

b) every other juridical civil relationship;

c) gifts, promises, favors, preferential treatment;

ç) possible negotiations for employment in the future by the official during the exercise of his function or negotiations for any other kind of form of relationships with a private interest for the official after leaving the duty performed by him during the exercise of duty;

d) engagements in private activity for the purpose of profit or any kind of activity incurring income, as well as engagements in profit-making and nonprofit organizations, syndicates or professional, political or state organizations and every other organization;

dh) relationships:

i) family or living together;

ii) the community;

iii) ethnic;

iv) religious;

v) recognized [relationships] of friendship or enmity;

e) prior engagements from which the interests mentioned in the above letters of this article have arisen or arise.

In Chapter III, Section 1 of the Law no.9367, dated 7.4.2005 as amended, are provided a range of limitations of the official's private interests to prevent conflict of interest in specific cases.

These restrictions are concentrated in three main directions:

- Prohibition of entering into contracts

- Prohibitions on receiving income because of a particular function

- Prohibition of receiving gifts, favors, promises or preferential treatment

Given the importance on preventing the conflict of interest, in the legislation is provided a set of prohibitions of entering into contracts with a

\footnotetext{
${ }^{6}$ Article 1 "Purpose" of the Law no.9367, dated 7.4.2005, as amended

${ }^{7}$ Article 5 of the Law no.9367, dated 7.4.2005, as amended
} 
public institution for a category of officials. Irrespective of the three main prohibitions above, this article is specifically focused on the prohibitions for public officials entering into contacts. The law on prevention of conflict of interest has devoted a special section for prevention of conflict of interest when entering in contracts (Article 21), considering a contract as a specific public decision, which, because of the importance and values of public property, is at risk to be damaged by the action of the private interests of the officials involved in this decision.

There are specific prohibitions on certain categories of officials, despite their role in entering into contracts with a public institution (points 1 , 2 and 6) and other prohibitions dependent on the role of the officer in decision making for these contracts (point 3).

Specifically point 1 of Article 21 of the law on conflict of interest specifies that:

"No individual, when he is equated with an official holding one of the functions defined in Chapter III, Section 2 of this law, judges and prosecutors at the first instance and appeal courts, and no commercial company, partnership or simple partnership, where this official possesses, actively or passively, shares parts of capital, at whatever amount, and cannot enter into a contract or sub-contract with any public institution".

Under the law are applied prohibitions for officials of middle management level only to the conclusion of contracts in the territory and jurisdiction of the institution, where the official works ${ }^{8}$. This prohibition is applied even if the party in the contract is a subordinate institution.

For the purposes of Article 21 paragraph 1 and 2, the limitation is applied only when the officer in relation to a public institution appears as an individual, natural commercial person, free professions or when as a party appears a legal entity in the form of a commercial organization when he has interests, such as shares or capital.

\section{Categories of officials having restrictions to enter into administrative contracts with public institutions}

Law no. 9367, dated 7.4.2005, as amended, explicitly defines who will be the officials with whom one is absolutely prohibited to benefit from contracts with a public party. Categories included in the ban are:

- $\quad$ The President of the Republic;

\footnotetext{
${ }^{8}$ Article 21, point 1 paragraph 2, of the law no.9367, dated 7.4.2005, as amended

"With regard to officials of medium management level provided for in Article 31 and the officials provided for in Article 32, Chapter III, Section 2, of this Law, the prohibition in accordance with the first paragraph of this point shall apply only in terms of entering into contracts within the territory and jurisdiction of the institution where the official works. This prohibition shall apply even where a subordinate institution is a party”.
} 
- $\quad$ The Prime Minister, the Deputy Prime Minister, ministers and deputy ministers;

- $\quad$ The members of Parliament;

- $\quad$ The Judges of the Constitutional Court of the Supreme Court; the members of the High Council of Justice (HCJ), the Attorney General, the Chief of the Supreme Audit Institution (SAI),

- The members of the Central Election Commission (CEC), the Ombudsman, the Inspector General of the High Inspectorate of Declaration and Audit of Assets and Conflict of interest (HIDAACI);

- The members of regulatory bodies (Supervisory Council of the Bank of Albania, including the Governor and Deputy Governor, competition, telecommunications, energy, water supply, insurance, securities, media);

- $\quad$ The General Secretaries, heads of departments, general directors and employees of mid-level managers of central institutions, as well as any other officer in every public institution, which is at least equivalent to the position of these officials,

- Judges and prosecutors at the court of first instance and of the appeal,

- $\quad$ Civil middle management level, but only to contracts concluded in the territory and their jurisdiction.

The paragraph 2 of Article 21 of Law 9367, dated 07.04.2005, as amended, foresees the prohibition of entering into contracts with a public party in local government. The law in this case has restricted this prohibition to exercise the jurisdiction and powers of the elected officers.

Specifically in Article 21 paragraph 2 of this law stipulates that:

"When the official is the mayor or deputy mayor of the municipality or county council, the relevant board member or official of the senior management level of a unit of local government, according to the interpretation of this term in the relevant laws, prohibition in paragraph 1 of this article, because of the private interests of the official defined at this point, applies only to the conclusion of contracts, where appropriate, with the municipality, the municipality or county council, where the official functions. This prohibition applies where a party to the contract is a public institution, depending on the unit".

So in this case, the restriction is applied only to contracts made by the municipality and their subordinate institutions, on the one hand and officials determine at this point, just that these officials have an interest in the kind covered in point 1 , explained above. This means that local officials are not ruling out the possibility of entering into contracts with any other public institution (central or local), excluding local institution where they perform the function. 
The prohibitions set forth in Article 21 paragraph 1 of the Law no. 9367, dated 07.04.2005, as amended, are applied in the same measure, even to persons related to the aforementioned officials ${ }^{9}$. According to the concept of Albanian law on prevention of conflict of interest, the circle of people connected with the officer consists of the spouse, cohabitant, adult children and parents of the official and those of the spouse and cohabitant.

\section{Types of prohibited contracts}

For the above categories of officials absolute prohibition includes, as a rule, all types of contracts: public procurement of construction, goods or services, sale, exchange, lease, donation, delivery, enterprise, transportation and any other contract which is not excluded by paragraph 4 of Article 21 of the law on the prevention of conflict of interests.

The law has provided exceptional cases, given the fact that the official may enter in contractual relationship with relevant institutions on various issues including cases relating to his employment, or when it finds adjustment to special laws for public purposes, etc.

Specifically Article 21.4 of the Law No.9367, dated 07.04.2005, as amended provides that:

The prohibitions arising from points 1,2 and 3 of this article are linked to cases when the conclusion of the contract: status;

a) relates to the employment in a public institution itself or its legal

b) relates to the receipt by the official of a service offered by public institutions or bodies and entities created by or under the control of the public, when these services are provided in the scope of activity of a public institution, and provided that service is not given preferentially officer or as preferential treatment in relation to others;

c) is based on the specific laws for public purposes or for special treatment of different categories of officials; alternative;

d) is necessary for the performance of public functions and there is no

e) has to do with a gift, favor or preferential treatment, in each case without counter, the subjects specified in paragraph 1 letters "a" and "b" and paragraph 2 of this article do in favor of a public institution ".

The amendments of the Law on prevention of conflict of interest approved by Law no. 86/2012 dated 09.18.2012, foresees that officers or

\footnotetext{
${ }^{9}$ Article 24, point 1 of the Law no. 9367, dated 07.04.2005, as amended provides that " 1 . The circle of persons related to the official, by way of applying the prohibitions set out in Articles 21 and 22 of this law, consist of the spouse, cohabitant, adult children and parents of the official and those of the spouse and cohabitant”.
} 
persons related to him, are prohibited to benefit from public contracts even through subcontracting. This provision in the law ${ }^{10}$ aims to prevent cases of finding possible clauses to avoid the legal restrictions, removing thus the possibility of fictitious participation in public procurements or administrative contracts, which effectively were realized through subcontracting, by those people who could not enter into contracts because of the legal restrictions ${ }^{11}$.

\section{Limitations due to the role of the official's decision to enforce contracts}

Law on Conflict of Interest no.9367, dated 07.04.2005, as amended, provides some other restrictions of the private interests of an official for preventing case by case conflicts of interests for particular instances.

Article 21.3 of the Law on Conflict of Interest specifies that:

"Notwithstanding the definitions in points 1 and 2 of this article, a contract may not be entered into force between the public institution and any public institution under this institution on the one side and a natural, civil or commercial natural person, or a legal person, or any other form of partnership on the other side, when the following conditions are met at the same time:

a) the official, that exercises his function in this public institution, has fundamental and definitive competence in the decision-making process in the evaluation of the offerors and the offers and the determination of the terms of the contract;

b) the official has private interests according to the definition of article 37 of the Code of Administrative Procedures and/or article 709 of the Civil Code or has an interest in the types of interests specified in points 1 and 2 of this article”.

In principle, any official in any position, even if that has an interest in the aforementioned type associated with a particular decision, leading to the signing of a contract with a public or party issuing a specific act, according law has only one option: "To declare private interests and to avoid, not taking part in decision-making. In contrary, contract or act that he produces will be null".

In the particular case that the officer involved in a specific decision has a private interest, as it is defined in Article 5 of the Law on Conflict of Interest (above), and does not declare that, regardless that they are known consequences, this constitutes an omission that is punishable

\footnotetext{
${ }^{10}$ Article 21 point 1 of the law no.9367, dated 07.04.2005, as amended

${ }^{11}$ Ballauri, F. "Conflict of interest in the criminal offenses committed by public officials /Konflikti i interesave në veprat penale të kryera nga punonjësit shtetërore ose në shërbim publik (Albanian version), Tirane 2015, p.158
} 
administratively under the law by a fine ${ }^{12}$ and has legal consequences. The act will be announced or found invalid ${ }^{13}$ depending on the type and extent of the violation.

If this omission has produced some harmful consequences (for unfair material profits, damage the legitimate interests of the state, the citizens and other legal persons) and is related to other actions related to a stable causeeffect link, the elements to refer the case to the prosecutor office for further investigations are sufficient.

Thus, the identification of private interest, leading to the official's violation of the law, would be a major component to prove the existence of the crime of abuse or illegal profit interests. This is why article 40/1 of law on prevention of conflict of interest provides the responsibility of the institution to send the case to the prosecution office in the cases when the official has acted unfaithfully by consuming elements of a criminal offense.

\section{The consequences of acts or contracts on conflict of interest}

Law on prevention of conflict of interests, Chapter V, Article 40, provides that administrative contracts and acts of every public institution, and appealing against them, issued under the conditions of an actual or apparent conflict of interests are invalid according to the meaning of this term and the principles and procedures defined in the Code of Administrative Procedures. On the other hand, it is foreseen that any civil contract entered into force in violation of this Law, or in any other case, when it is related to the presence of an actual or apparent conflict interest, does not create any legal consequence ${ }^{14}$.

In cases where a conflict of interest constitutes an act or contract of absolute nullity, the request for its finding can be made at any time. The absolute invalidity of the act may be declared at any time, either ex officio or upon request of any interested person, by the public institution that has issued it, its superior organ, or the organ which is competent to review the administrative legal remedies and by the competent court for administrative issues, in accordance with the law. In case only a part of the act is absolutely invalid, and such part is so important that the public body would not have issued the act without it, the whole act shall be absolutely invalid ${ }^{15}$. The effects of the repeal or revocation start and are regulated by the provisions of the Administrative Procedure Code.

\footnotetext{
12 Article 44 of the Law no.9367, dated 10.04.2005 "On the Prevention of Conflict of interest..”, as ammended.

${ }^{13}$ Depending on the type of violation if we are dealing with absolute or relative invalidity

${ }^{14}$ Article 40, point 2, of the Law nr.9367, dated 7.4.2005 "On the Prevention of Conflict of interest..” as ammended.

${ }^{15}$ Article 110 of the Albanian Code of Administrative Procedure.
} 
The amendmends that are made to the Law 9367, dated 04.07.2005, with the law 44/2014, foresee several legal instruments to regulate the legal consequences obtained in a conflict of interest in cases where the responsible institutions does not provide solutions.

Article 44 of the Law 9367, dated 04.07.2005, as amended, specifically foresees that an infringement of obligations set out in this law, as long as it does not constitute a criminal offence, shall be an administrative infraction and shall be sentenced with a penalty that varies from 100.000 ALL to 300.000 ALL depending on the violation.

Fines and disciplinary measures taken against officials who commit a conflict of interest are only a part of the punishment and measures provided by law. The most important instrument that should be implemented as a form of punishment of violations, rests in the invalidation of an act under the condition of a conflict of interest, to the open trial process to such a case, to the possibility of retrospective and compensation the damage to the parties and passing the entire burden of damage, including moral damages that may be caused to a public institution, to the responsible official who has acted in terms of conflict of interest ${ }^{16}$.

Law on prevention of conflict of interest sanctions in its article no. 40/1/2 the obligation of public institutions, since their act becomes invalid due to conflict of interests, and should take disciplinary punishment procedures of officials acted in bad faith; shifting the burden of compensation for the damage inflicted to the official, asking the court to order compensation for moral damage caused by illegal actions of this official; as well as file criminal charges against the official, if the infringement committed by him is considered to constitute a criminal offence.

In case the public institution itself does not take the initiative under this point, the superior institution shall, in a hierarchical way based on their legal power, perform the obligations set out herein. In case of their omission, the actions provided in letter "a", point 2, shall be performed by the High Inspectorate for the Declaration and Audit of Assets and Conflict of Interests (HIDAACI), which shall, as appropriate, cooperate with the State Advocacy (Article 40/1/2).

The criminal offenses directly relates to violations in public procurement are enshrined by Article 258 of the Albanian Criminal Code which provides that:

"Breaching the equality of participants in public bids or auctions

${ }^{16}$ Ballauri, F. "Conflict of interest in the criminal offenses committed by public officials /Konflikti i interesave në veprat penale të kryera nga punonjësit shtetërore ose në shërbim publik (Albanian version), Tirane 2015, p.69 
Committing actions in breach of the laws which regulate the freedom of participants and the equality of citizens in bids and public auctions, by $a$ person holding state functions or public service in order to create illegal advantage or benefits for third parties, is punishable up to three years imprisonment".

In the analysis of the inevitable connection that exists between conflict of interest and the criminal offenses in breaching the equality of participants in public bids or auctions or corruption offenses, is to mention a practical case in the Supreme Court.

The Supreme Court Decision no. 269 of 2012 has reversed the decision of the Court of Appeal that had decided the innocence of two defendants for the offense of violation of equality in tenders as provided in Article 258 of the Criminal Code. Criminal Chamber upheld the decision of the first instance court, which sentenced two officials, L.M in the position of the Mayor and the Chairman of the Procuring Entity and Gj.M in the position of Deputy Mayor and Chairman of the Evaluation Committee of procurement, bidding for the criminal act provided by article 258 of the Criminal Code.

In the decision the Supreme Court inter alia noted that the defendants by their illegal actions have favored a private entity in the tendering procedures of public funds to the detriment of other subjects participating in the tender conducted on 27.03.2008. Criminal Chamber of the Supreme Court concluded that "the Bid Evaluation Committee has not been investigated in connection with the conflict of interest of the candidates".

In this case the position of the operator's legal representatives, who held the function at the same time as the member of the Municipal Council, constitute a legal reason for disqualification of the company he represented, pursuant to Law no. 9643, dated 20.11.2006 “On Public Procurement”, as amended, and Law no.9367, dated 7.4.2005 "On the prevention of conflicts of interest ..” as amended. This conflict of interest untreated and unsolved on time (before the beginning the procurement procedures) has lead the possibility of the consumption of the offense of breaching the equality of participants in public bids or auctions.

Despite the risk of conflict of interest in public procurement and managing administrative contracts there are no data recorded on cases identified or avoided of conflict of interest in this field. If we refer to the annual reports of the Public Procurement Agency ${ }^{17}$, where are provided general statistical data for public procurement that have been completed or

17 The Annual Reports of Public Procurement Agency are public on the web page www.app.gov.al . 
cancelled, there are no specific data about the reason for the cancelation, if the cancellation was because of conflict of interest or other causes.

\section{Conclusion}

Law on prevention of conflict of interests provides special restrictions and prohibitions on the private interests for officials exercising public functions, depending on their functions, responsibilities and competencies in public decision-making. These prohibitions - in a certain category - are extended even to persons connected to the official (husband/wife, cohabitant/wife, adult children, parents of the official and his/her spouse). In principle, the law obliges officials not to participate in those decisions, when they or their family members have any interest directly or indirectly.

In addition, this law in its Articles 21-24 provides some prohibitions and restrictions on officials to enter into contract with a public institution, prohibitions on providing income due to the special function, as well as bans on receiving gifts, favors and preferential treatments. These restrictions are intended primarily to protect the interests of citizens from any influence of public officials who, in view of their interests or their relatives, in an administrative process, may harm the interests of the state, citizens or legal persons.

While emphasizing that a situation of conflict of interest can be potentially associated with a criminal offense of corruption, abuse of power, violation of equality in public bids or unlawful profit of interests, it is legitimized that, in the framework of prevention, by law, several specific restrictions on private interests of the public officials are provided.

\section{References:}

1. OECD Guidelines for the management of conflicts of interest in public service, June 2003.

2. Bruno W. Speck, Conflict of Interest: Concepts, Rules and Practices regarding Legislators in Latin America, The Latin Americanist, Volume 49, Issue 2, 2008.

3. Ballauri, F. "Conflict of interest in the criminal offenses committed by public officials / Konflikti i interesave në veprat penale të kryera nga punonjësit shtetërore ose në shërbim publik (Albanian version), Tirane 2015, http://www.doktoratura.unitir.edu.al/tag/doktoraturafjorida-ballauri-kallco.

4. The Albanian Code of Administrative Procedure, adopted by Law No. 44/2015.

5. The Criminal Code of the Republic of Albania.

6. The Civil Code of the Republic of Albania. 
7. Law 9367, dated 07.04.2005, "On the prevention of conflict of interest in the exercise of public functions", as amended.

8. Law no.9049, dated 04.10.2003, "On the declaration and audit of assets, financial obligations of elected persons and certain public officials" as amended.

9. Law nr.9131, dated 09.08.2003 "On the rules of ethics in public administration”.

10. Law No 9643, dated 20.11.2006 "On public procurement" as amended . 